\title{
Impact of heterophylly on the sensitivity of Myriophyllum aquaticum biotests
}

\author{
Klaus Peter Ebke ${ }^{1 *}$, Christian Felten ${ }^{2}$ and László Dören ${ }^{1}$
}

\begin{abstract}
Background: Parrot feather (Myriophyllum aquaticum) is an amphibious macrophyte with an inducible heterophylly. M. aquaticum plants adapted to the emersed state have leaves with a distinct cuticle and water repellent properties. In contrast M. aquaticum plants adapted to the submerged state have leaves typical for submerged hydrophytes with a strongly reduced cuticle. The aim of the study was to evaluate if this heterophylly of M. aquaticum affects the results of macrophyte biotests. Therefore, the two model substances atrazine and 2,4-dichlorophenoxyacetic acid (2,4-D) were tested each with three $M$. aquaticum biotests, the only modified parameter being the adaptation time to submergence $(0,7,28$ days).

Results: Root length was the most sensitive growth endpoint regarding the test substances atrazine and 2,4-D. Biotests with plants adapted to the submerged state show three times more sensitive results (EC507d $142.2 \mu \mathrm{g} / \mathrm{L}$, $\mathrm{EC50}_{28 \mathrm{~d}} 154.5 \mu \mathrm{g} / \mathrm{L}$ ) than biotests with plants without an adaptation phase ( $\left(\mathrm{EC50}_{\mathrm{od}} 458.8 \mathrm{\mu g} / \mathrm{L}\right)$ in case of atrazine and five times more sensitive results $\left(\mathrm{EC}^{2} \mathrm{O}_{28 \mathrm{~d}} 46.9 \mu \mathrm{g} / \mathrm{L}, \mathrm{EC} 50_{\mathrm{Od}} 246.3 \mu \mathrm{g} / \mathrm{L}\right)$ in case of 2,4-D. Apart from the differences in sensitivity, the differently adapted M. aquaticum plants show a completely different growth behavior. The growth rates based on shoot length were nearly ten times higher in the biotests with not adapted $M$. aquaticum plants than in the biotests with plants 28 days adapted to submergence. Additional measurements of the quantum yield of PSI/ could demonstrate that rapid growth in length is not based on photosynthetic carbon assimilation.

Conclusions: The heterophylly of $M$. aquaticum affects significantly the sensitivity of aquatic macrophyte biotests and should be taken into account in the development of a standardized test design. The 2,4-D results show the importance of an additional macrophyte biotest to the Lemna test, where the no observed effect concentration (NOEC) value is more than 30 times lower $(7 \mu \mathrm{g} / \mathrm{L})$ than the NOEC value of Lemna in the literature $(270 \mu \mathrm{g} / \mathrm{L})$. Furthermore, the growth rate endpoint in macrophyte biotests should not be misinterpreted. Rapid shoot elongation of amphibious macrophytes, which become submerged, is mainly caused by ethylene-triggered endogenous processes that are not connected to photosynthetic carbon assimilation and appear to be part of a stress reaction to avoid adverse environmental conditions.
\end{abstract}

Keywords: Macrophyte biotests, Myriophyllum aquaticum, Heterophylly, Quantum yield of PSII, Atrazine, 2,4-D, Ethylene-induced shoot elongation

\section{Background}

Macrophytes are a very important component of aquatic ecosystems. They influence the physical (light, temperature, hydrodynamics, and substrate) and the chemical (oxygen, carbon, and nutrients) properties of aquatic ecosystems [1,2]. In addition, they offer habitat [3] and

\footnotetext{
* Correspondence: ebke@mesocosm.de

'Institute for Water Protection MESOCOSM GmbH, Research Centre

Neu-Ulrichstein, Homberg (Ohm) 35315, Germany

Full list of author information is available at the end of the article
}

food [4,5] for animals and influence algal growth by competition and allelopathy [6]. Beside their crucial ecosystem role, macrophytes are presently only represented by the duckweed Lemna in herbicide risk assessment in Europe [7]. In specific cases, for instance auxin-simulating herbicides, the toxicity to aquatic macrophytes could be underestimated $[8,9]$ if monocotyledonous plants like Lemna show a less sensitivity against the test item than dicotyledonous plants.

\section{空}

(c) 2013 Ebke et al.; licensee Springer. This is an Open Access article distributed under the terms of the Creative Commons Attribution License (http://creativecommons.org/licenses/by/2.0), which permits unrestricted use, distribution, and reproduction in any medium, provided the original work is properly cited. 
The German Federal Environment Agency developed recently an axenic, sediment-free macrophyte biotest with the Eurasian watermilfoil (Myriophyllum spicatum) [10], and the SETAC expert group AMEG suggests a non-axenic macrophyte biotest with sediment with $M$. spicatum and Myriophyllum aquaticum as an additional test beside Lemna in herbicide risk assessment [11,12]. Both Myriophyllum species are dicotyledonous, rooted macrophytes, which will be a meaningful compliment to the monocotyledonous, free-floating macrophyte Lemna. These species show high growth rates and a high potential of vegetative reproduction via scions and are relatively easy to handle in the laboratory $[13,14]$, which are important qualifications for macrophyte biotests.

However, the development of a biotest with Parrot feather (M. aquaticum) should take account of its ecology. It is an amphibious macrophyte: it grows emergent in wetlands as well as submerged in water bodies. As an adaptation to these different environmental conditions, $M$. aquaticum reacts with a distinct heterophylly. Thus, $M$. aquaticum features two morphologically and physiologically different types of leaves according to the adaptation to its environment (for a deeper understanding of heterophylly of semi-aquatic macrophytes see [15]). The solid leaves adapted to the emersed state show specific properties of helophytes; a distinct cuticle restricts evaporation and avoids the infiltration of pathogenic microorganisms. Moreover, the surface of emergent leaves of M. aquaticum has a special micromorphology, which causes the so-called lotus effect. The three-dimensional wax plates on the leaf surface are responsible for its water repellent properties [16,17]. If $M$. aquaticum, which is adapted to the emersed state, gets submerged, an air layer covers the plant. Thus, there is no contact between the water respectively to the test medium in a biotest and the macrophyte (see Figure $1 \mathrm{~A}$ or the video in Additional file 1). In contrast, the leaves of $M$. aquaticum adapted to the submerged state show specific properties of submerged hydrophytes (see the video in Additional file 2). The filigree pinnation and the reduced cuticle of the leaves improve their supply with carbon dioxide and dissolved nutrients directly from the water. This inducible heterophylly of $M$. aquaticum leads not only to two different morphological phenotypes (see Figure $1 B, C)$. It also affects the barrier trait of its cuticle. From the ecotoxicological point of view, the following question has to be asked: Does the heterophylly of $M$. aquaticum has an impact on the bioavailability of the test substances and therefore on the sensitivity of biotests with this species?

The aim of this study was to investigate this assumption with the two herbicides atrazine and 2,4-dichlorophenoxyacetic acid (2,4-D) as model substances. Atrazine represents photosystem II (PSII) inhibitors and is particularly suitable for validation of the PAM technique in macrophyte biotests, which allows detection of the quantum yield of PSII. This is an indication of the functionality and the efficiency of the photosystem and a powerful tool in addition to the growth parameters to detect stress in plants. In a recent comparative study [18], the toxicity of atrazine was in the same range for $M$. aquaticum without the adaptation phase and Lemna minor $\left(\mathrm{EC} 50_{M}\right.$. aquaticum $93.51 \mu \mathrm{g} / \mathrm{L}$ respective $\mathrm{EC} 50_{L}$. minor $121.85 \mu \mathrm{g} / \mathrm{L}$ ). 2,4-D represents synthetic auxine herbicides, which are in the focus of the discussion regarding the necessity of additional macrophyte biotests $[8,9,11]$. Because of its selective mode of action, it is stated that the toxicity of 2,4-D to dicotyledonous macrophytes is underestimated by the Lemna test [8].

\section{Results and discussion}

\section{Chemical analysis of test medium (water)}

The initial exposure with 2,4-D to the test systems reached $105 \%$ of the nominal loading measured $1 \mathrm{~h}$ after application. The water samples from the tests with atrazine showed 80 to $90 \%$ recovery of the nominal concentrations $1 \mathrm{~h}$ after application. The range of variation between the highest test concentrations of the three biotests were $<1 \%$ for $2,4-\mathrm{D}$ and 7 to $11 \%$ for atrazine. Averaged concentrations of 2,4-D were in the range of the nominal concentration. Averaged concentrations of atrazine were 7 to $18 \%$ below the nominal concentration (Table 1).

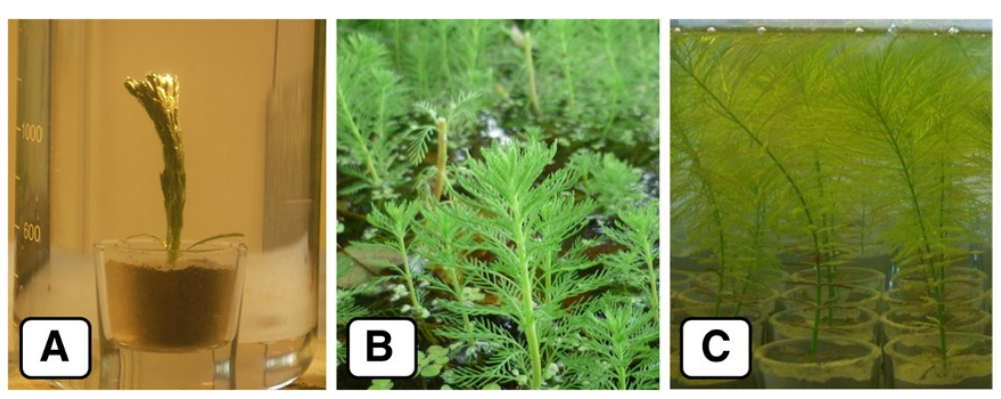

Figure $1 \mathbf{M}$. aquaticum adapted to different states. (A) Lotus effect of M. aquaticum adapted to an emersed state. (B) M. aquaticum adapted to an emersed state and (C) submerged state. 
Table 1 Concentrations measured $1 \mathrm{~h}$ after application of the test substances $\left(\mu \mathrm{g} \mathrm{L}^{-1}\right)$

\begin{tabular}{lcc}
\hline & $\begin{array}{c}\text { 2,4-D } \\
(\boldsymbol{\mu g} \text { a.i./L) }\end{array}$ & $\begin{array}{c}\text { Atrazine } \\
(\boldsymbol{\mu} \mathbf{g} \text { a.i./L) }\end{array}$ \\
\hline Nominal concentration & 2,000 & 640 \\
Measured concentration (0-day adaptation test) & 2,099 & 523 \\
Measured concentration (7-day adaptation test) & 2,099 & 596 \\
Measured concentration (28-day adaptation test) & 2,107 & 589 \\
\hline
\end{tabular}

The highest concentrations are shown for the three biotest adaptation times to submergence $(0,7,28$ days).

\section{Growth}

The results of the growth endpoints (NOEC, LOEC, and EC $x$ ) are listed in Table 2 for the atrazine tests and in Table 3 for the 2,4-D tests. In both cases, the root length is the most sensitive endpoint. To visualize the impact of the adaptation time of the test organisms to the submerged state, the results of the root length endpoint are shown in Figure 2. The sensitivities of the 7-day (EC50 $142.2 \mu \mathrm{g} / \mathrm{L}$ ) and 28-day (EC50 $154.5 \mu \mathrm{g} / \mathrm{L}$ ) adapted test organisms indicated by root length are about three times higher than the sensitivity of the test organisms without adaptation time (EC50 $458.8 \mu \mathrm{g} / \mathrm{L}$ ) regarding atrazine. The atrazine EC50 of the adapted $M$. aquaticum is in the same range as the EC50 of the related species Myriophyllum heterophyllum in the literature (EC50 132 $\mu \mathrm{g} / \mathrm{L}[19])$, which is an exclusively submerged macrophyte. The 2,4-D treatment shows even higher differences in the sensitivity of the test organisms according to their adaptation state. The EC50 indicated by the root length of the 28-day adapted plants (EC50 $46.9 \mu \mathrm{g} / \mathrm{L}$ ) is about three times lower than the EC50 of the 7-day adapted plants (EC50 $157.8 \mu \mathrm{g} / \mathrm{L}$ ) and about five times lower than the EC50 of the plants without adaptation time (EC50 $246.3 \mu \mathrm{g} / \mathrm{L})$. The LOEC value indicated by the root length of $M$. aquaticum with a 28-day adaptation time is even 16 times lower than the LOEC value of $M$. aquaticum without adaptation to the submerged state.

In the axenic test system with $M$. aquaticum, recommended by Turgut and Fomin [20], where the plants are cultured in the submerged state, the most sensitive endpoint is also the root length with an EC50 of 50 $\mu \mathrm{g} / \mathrm{L}$ [21], which is very similar to the EC50 of this study.

These results prove the thesis that the heterophylly of $M$. aquaticum has a significant influence to aquatic biotests. Particularly, the reduced cuticle of submerged macrophytes improves the bioavailability to organic and inorganic compounds in the aquatic environment. On the one hand, this study underlines the importance of the consideration of the ecological and morphological characteristics of aquatic macrophytes, which is with $M$. aquaticum only, using plants with adaptation to the submerged state. On the other hand, it attests $M$. aquaticum to be a sensitive macrophyte for herbicide risk assessment, when submerged preculture conditions are applied. In a study where the impact of 2,4-D on the growth of nine aquatic macrophytes were investigated [22], the most sensitive species was Ranunculus aquatilis with an EC50 value of $92 \mu \mathrm{g} / \mathrm{L}$ (root length), which is twice as high as the EC50 of M. aquaticum in this study with plants adapted to the submerged state. Furthermore, the EC50 of Lemna gibba in the 2,4-D review report of the European Commission is $580 \mu \mathrm{g} / \mathrm{L}$ [23] more than ten times higher than the EC50 of M. aquaticum with $46.9 \mu \mathrm{g} / \mathrm{L}$. The NOEC of 2,4-D regarding Lemna is $270 \mu \mathrm{g} / \mathrm{L}$, while the NOEC regarding M. aquaticum in this study is $7 \mu \mathrm{g} / \mathrm{L}$ more than 30 times lower.

Table 2 NOEC, LOEC, EC50, and EC10 values of the atrazine tests regarding growth

\begin{tabular}{|c|c|c|c|c|}
\hline Adaptation time to the submerged state & $\begin{array}{c}\text { NOEC } \\
(\mu \mathrm{g} \text { a.i./L) }\end{array}$ & $\begin{array}{c}\text { LOEC } \\
(\mu \mathrm{g} \text { a.i./L) }\end{array}$ & $\begin{array}{c}\text { EC50 (95\% confidence interval) } \\
(\mu \mathrm{g} \text { a.i./L) }\end{array}$ & $\begin{array}{c}\text { EC10 (95\% confidence interval) } \\
(\mu \mathrm{g} \text { a.i./L) }\end{array}$ \\
\hline \multicolumn{5}{|l|}{ Fresh weight } \\
\hline no & 160 & 640 & 680.6 (very wide ${ }^{a}$ ) & 562.6 (very wide ${ }^{a}$ ) \\
\hline 7 days & 40 & 160 & 438.9 (200.2 to 962.4$)$ & $60.2(10.1$ to 360.6$)$ \\
\hline 28 days & 160 & 640 & 645.3 (467.1 to 891.4) & $112.2(54.1$ to 232.8$)$ \\
\hline \multicolumn{5}{|l|}{ Shoot length } \\
\hline no & 160 & 640 & 714.7 (very wide ${ }^{a}$ ) & 608.0 (very wide ${ }^{a}$ ) \\
\hline 7 days & 40 & 160 & 965.1 (714.8 to 1303$)$ & 87.4 (54.6 to 139.7$)$ \\
\hline 28 days & $>640$ & $>640$ & 857.9 (very wide) & 819.8 (very wide) \\
\hline \multicolumn{5}{|l|}{ Root length } \\
\hline no & 160 & 640 & 458.8 (414.9 to 507.3$)$ & 207.0 (157.8 to 271.6) \\
\hline 7 days & 40 & 160 & 142.2 (very wide ${ }^{a}$ ) & 125.6 (very wide ${ }^{\mathrm{a}}$ ) \\
\hline 28 days & 160 & 640 & 154.5 (very wide ${ }^{\mathrm{a}}$ ) & 134.7 (very wide ${ }^{\mathrm{a}}$ ) \\
\hline
\end{tabular}


Table 3 LOEC, EC50, and EC10 values of the 2,4-D tests regarding growth

\begin{tabular}{|c|c|c|c|c|}
\hline Adaptation time to the submerged state & $\begin{array}{c}\text { NOEC } \\
(\mu \mathrm{g} \text { a.i./L) }\end{array}$ & $\begin{array}{c}\text { LOEC } \\
(\mu \mathrm{g} \text { a.i. } / \mathrm{L})\end{array}$ & $\begin{array}{c}\text { EC50 (95\% confidence interval) } \\
\text { ( } \mu \mathrm{g} \text { a.i. } / \mathrm{L})\end{array}$ & $\begin{array}{c}\text { EC10 (95\% confidence interval) } \\
(\mu \mathrm{g} \text { a.i. } / \mathrm{L})\end{array}$ \\
\hline \multicolumn{5}{|l|}{ Fresh weight } \\
\hline no & $>2,000$ & $>2,000$ & $>2,000$ & 123.1 (26.7 to 568.4$)$ \\
\hline 7 days & $>2,000$ & $>2,000$ & $>2,000$ & $>2,000$ \\
\hline 28 days & 500 & 2,000 & $>2,000$ & $1,918(1,917$ to 1,918$)$ \\
\hline \multicolumn{5}{|l|}{ Shoot length } \\
\hline no & $>2,000$ & $>2,000$ & $>2,000$ & $>2,000$ \\
\hline 7 days & $>2,000$ & $>2,000$ & $>2,000$ & $>2,000$ \\
\hline 28 days & 500 & 2,000 & $3,835(3,822$ to 3,848$)$ & 1122 (259.4 to 4852) \\
\hline \multicolumn{5}{|l|}{ Root length } \\
\hline no & 125 & 500 & 264.3 (101.3 to 689.3) & 26.5 (3.1 to 229.5$)$ \\
\hline 7 days & 31.25 & 125 & 157.8 (76.7 to 324.5$)$ & $30.3(6.2$ to 148.0$)$ \\
\hline 28 days & 7 & 31.25 & 46.9 (34.1 to 64.5$)$ & $9.2(4.5$ to 18.7$)$ \\
\hline
\end{tabular}

LOEC values are calculated by Dunnet's multiple comparison test. $E C x$ values are determined by non-linear regression analysis of the concentration-response curve.

\section{Quantum yield of PSII}

The results of the photosynthesis endpoint quantum yield of PSII (Figure 3B and Table 4) in all adaptation states of $M$. aquaticum show that negative effects on the plants occur at the lowest tested atrazine concentration of $10 \mu \mathrm{g} / \mathrm{L}$. The EC50 of the test organisms without submerged adaptation time is $135.1 \mu \mathrm{g} / \mathrm{L}$, the most sensitive concentration value compared to the EC50 of the 7-day adapted plants $(386.2 \mu \mathrm{g} / \mathrm{L})$ and 28 -day adapted plants $(270.2 \mu \mathrm{g} / \mathrm{L})$. On the first sight, this seems to be an

\section{A atrazine tests - root length}

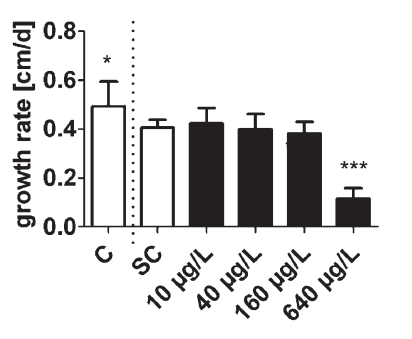

no adaption time

\section{B 2,4-D tests - root length}

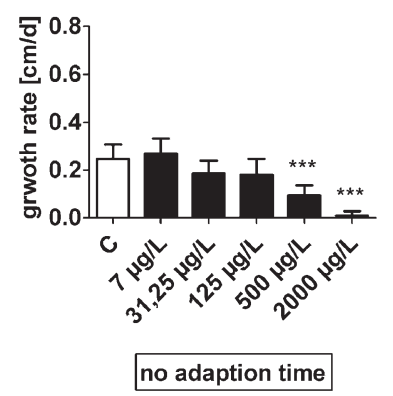

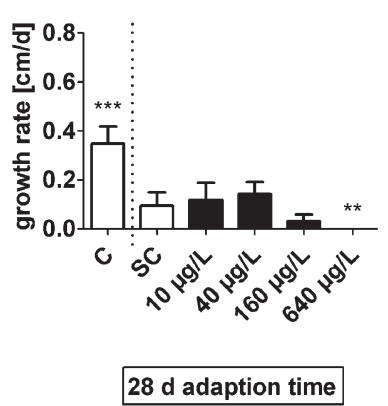

$7 \mathrm{~d}$ adaption time

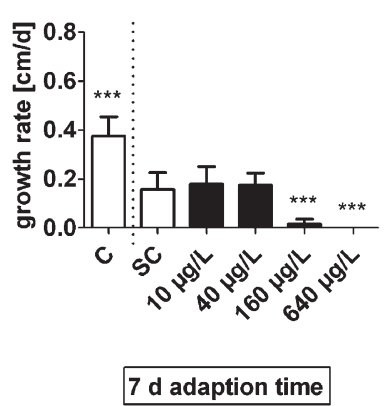

$28 \mathrm{~d}$ adaption time

\footnotetext{
Figure 2 Average specific growth rates regarding root length under atrazine (A) and 2,4-D (B) impacts. Values are expressed as mean values \pm standard deviation. Significant difference to SC (atrazine) or C (2,4-D) calculated by Dunnet's multiple comparison test. Asterisk denotes $p<0.05$; double asterisk, $p<0.01$; and triple asterisk, $p<0.001$. C, control; SC, solvent control.
} 
A atrazine tests - shoot length
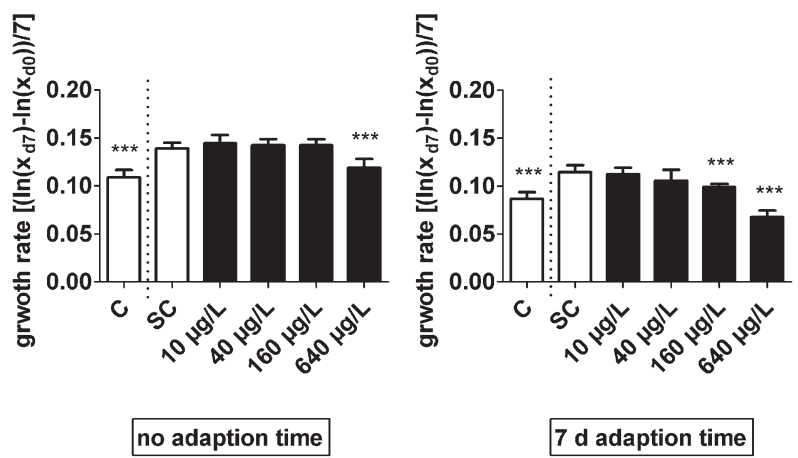

$7 \mathrm{~d}$ adaption time

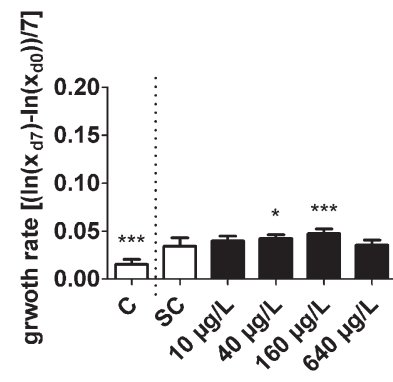

$28 \mathrm{~d}$ adaption time

B atrazine tests- quantum yield of PSII

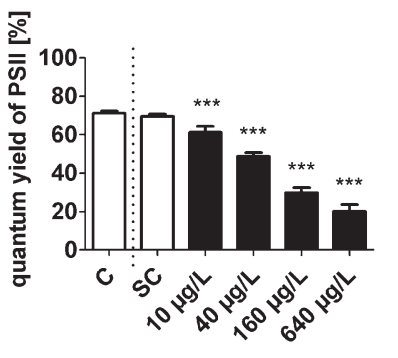

no adaption time

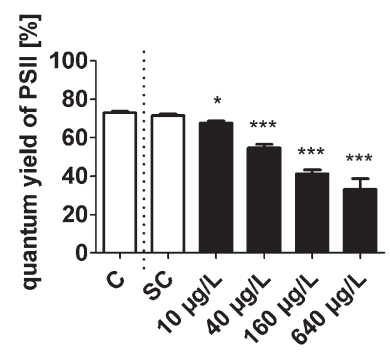

$7 \mathrm{~d}$ adaption time

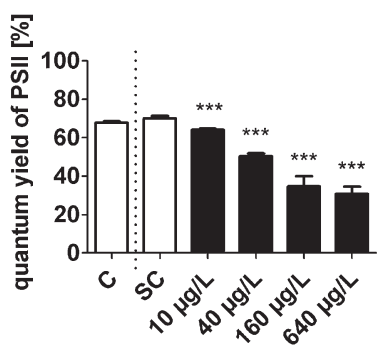

$28 \mathrm{~d}$ adaption time

Figure 3 Comparison of the average specific growth rates. Shoot length (A) and quantum yield of PSII (B) at the end of the test under atrazine impact. Values are expressed as mean values \pm standard deviation. Significant difference of SC (atrazine) calculated by Dunnet's multiple comparison test. Asterisk denotes $p<0.05$; triple asterisk, $p<0.001$. C, control; SC, solvent control.

antagonism in view of the growth results. However, the interpretation of the quantum yield of PSII data has to take account that these measurements were only performed at the end of the tests, 7 days after application. In another macrophyte study with atrazine [13], it was shown that the negative effect on the quantum yield of PSII caused by atrazine decreases with time. The fact that, 7 days after atrazine application, the inhibition of the quantum yield of PSII is higher in the unadapted plants than in the adapted plants is a hint that the entry into the plant had occurred at a delayed time.

Apart from the ecotoxicological view, the quantum yield of PSII results in combination with the shoot length results delivers a further step in understanding growth behavior of $M$. aquaticum. The highest growth rates occur at the non-adapted plants, while the lowest growth rates occur at the 28-day adapted plants (see Figure 3A). Especially, the control group of the 28-day adapted plants shows very low growth rates $\left(\mu_{\mathrm{C}} 0.015\right)$. The shoot length growth rates of the plants without adaptation to the submerged state are nearly ten times higher $\left(\mu_{\mathrm{C}} 0.11, \mu_{\mathrm{SC}} 0.14\right)$, but the quantum yield of PSII, which correlates with photosynthetic carbon assimilation [38], is very similar, independent from the adaptation to the submerged state (see Figure $3 \mathrm{~B}$ ). This leads to the syllogism that the high growth rates of the non-adapted $M$. aquaticum plants in this test cannot be explained only by carbon assimilation.

Table 4 NOEC, LOEC, EC50, and EC10 values of the atrazine tests regarding photosynthesis

\begin{tabular}{lcccc}
\hline $\begin{array}{l}\text { Adaptation time to the submerged } \\
\text { state (quantum yield of PSII) }\end{array}$ & NOEC $(\boldsymbol{\mu g}$ a.i./L) & LOEC ( $\boldsymbol{\mu g}$ a.i./L) & $\begin{array}{c}\text { EC50 (95\% confidence interval) } \\
\text { ( } \boldsymbol{\mu g} \text { a.i./L) }\end{array}$ & $\begin{array}{c}\text { EC10 (95\% confidence interval) } \\
\text { ( } \boldsymbol{\mu g} \text { a.i./L) }\end{array}$ \\
\hline no & $<10$ & 10 & $135.1(69.1$ to 264.3$)$ & 5.5 (1.0 to 30.9$)$ \\
7 days & $<10$ & 10 & $386(99.9$ to 1,493$)$ & $8.1(0.4$ to 170.6$)$ \\
28 days & $<10$ & 10 & $270.2(50.7$ to 1,441$)$ & $4.4(0.1$ to 308.6$)$ \\
\hline
\end{tabular}

LOEC values are calculated by Dunnet's multiple comparison test. EC $x$ values are determined by non-linear regression analysis of the concentration-response curve. 


\section{Rapid extension growth}

Now, we come to a second special ecological characteristic of some macrophytes, which has taken into account the development of a standardized macrophyte test with $M$. aquaticum. The super growth event of amphibious plants occurs when submerged. This rapid extension growth is an adaptation of many amphibious macrophytes from widely dispersed families to bring aerial parts which become submerged up to the water surface [24]. It is a hormone-regulated strategy to avoid flooding stress, where the gaseous plant hormone ethylene plays the key role $[24,25]$ in a complex interaction with abscisic acid, gibberellins, and auxins [26]. This rapid extension growth is based on cell elongation and accelerated cell division, which is attended by the consumption of energy and solutes [26]. The main source of this energy and solutes are storage compounds (starch) and the reallocation of dry matter [26,27]. Partial $\mathrm{O}_{2}$ shortage and $\mathrm{CO}_{2}$ enrichment can amplify this stimulated elongation [28]. This explains why the control group without ethanol as a solvent shows less growth rate regarding shoot length than the solvent control and the treatment groups (Figure 3A) because already least concentrations of ethanol cause a decline in $\mathrm{O}_{2}$ and increase of $\mathrm{CO}_{2}$ in the water in consequence of its microbial degradation.

\section{Hormesis}

The last point is related to the discussion on the hormesis phenomenon. The growth rates of the 28-day adapted plants regarding shoot length show a significant increase at 40 and $160 \mu \mathrm{g} / \mathrm{L}$, while the quantum yield of PSII shows a significant inhibition at these atrazine concentrations (Figure 3). On the contrary, the stimulated growth of submerged macrophytes could be part of a strategy to avoid stress in the environment demands further discussion on how to handle such results in herbicide risk assessment. An increased growth rate of cultivated emersed and, in the test, submerged macrophytes appears more to be an indication of stress than a beneficial stimulation of growth. Atrazine for example has an influence on the auxin metabolism of plants $[29,30]$, which also plays a role in the shoot elongation of submerged macrophytes [26], while auxin herbicides, like 2,4-D, not only affect the auxin metabolism but also induce an increased ethylene biosynthesis [31,32].

\section{Conclusions}

The heterophylly of $M$. aquaticum has a significant impact on the sensitivity of aquatic macrophyte biotests with this species. M. aquaticum plants adapted to the emersed state show less sensitivity against the tested herbicides atrazine and 2,4-D than plants adapted to the submerged state. The distinct cuticle and the water repellent properties of emersed adapted leaves of $M$. aquaticum reduce significantly the bioavailability of test substances. The study shows that M. aquaticum, when adapted to the submerged state, is suitable for a standard macrophyte test species and could be a complement to the Lemna test of high informative value. In particular, the root length endpoint shows within this biotest a high sensitivity to the tested herbicides (see also [33]).

Finally, this study put a spotlight on the growth behavior of aquatic macrophytes, in particular amphibious ones, and its consequences for ecotoxicological tests. High shoot growth rates of amphibious macrophytes, which become submerged, are primarily a result of hormone-regulated endogenous processes and only to a part a result of photosynthetic carbon assimilation.

\section{Methods}

\section{Test design}

The $M$. aquaticum test organisms were taxonomically identified by using a specific key for aquatic macrophytes [34]. They were cultivated in the emersed state under the same conditions regarding sediment, light, and temperature as the test conditions. They were irrigated with a Steinberg medium diluted 1:1 with deionized water (see Table 5). The two test substances atrazine and 2,4-D were tested in three different $M$. aquaticum biotests. The first test used emersed test organisms with no adaptation to the submerged state. The second test used plants, which were 7 days adapted to the submerged state before the test started. The third test used plants, which were 28 days adapted to the submerged state before the test started. For the adaptation phase, the head whorls of the plants (length $8 \mathrm{~cm}$ ) were put in artificial sediment in a $40-\mathrm{mL}$ beaker and were submerged into the Steinberg medium diluted 1:1 with deionized water. Similarly for the tests, three head whorls (length $6 \mathrm{~cm}$ ) in 40 -mL beakers with $50 \mathrm{~g}$ of artificial sediment were put in a high 2,000-mL beaker with

\section{Table 5 Composition of the Steinberg medium}

\begin{tabular}{lcc}
\hline Nutrients & $\begin{array}{c}\text { Steinberg } \\
\text { medium (mg/L) }\end{array}$ & $\begin{array}{c}\text { Steinberg medium diluted 1:1 } \\
\text { with deionized water (mg/L) }\end{array}$ \\
\hline $\mathrm{KNO}_{3}$ & 350 & 175 \\
$\mathrm{KH}_{2} \mathrm{PO}_{4}$ & 90 & 45 \\
$\mathrm{~K}_{2} \mathrm{HPO}_{4}$ & 12.6 & 6.3 \\
$\mathrm{MgSO}_{4} \cdot 7 \mathrm{H}_{2} \mathrm{O}$ & 100 & 50 \\
$\mathrm{Ca}\left(\mathrm{NO}_{3}\right)_{2} \cdot 4 \mathrm{H}_{2} \mathrm{O}$ & 295 & 147.5 \\
$\mathrm{H}_{3} \mathrm{BO}_{3}$ & 0.12 & 0.06 \\
$\mathrm{ZnSO}_{4} \cdot 7 \mathrm{H}_{2} \mathrm{O}$ & 0.18 & 0.09 \\
$\mathrm{Na}_{2} \mathrm{MoO}_{4} \cdot 2 \mathrm{H}_{2} \mathrm{O}$ & 0.044 & 0.022 \\
$\mathrm{MnCl}_{2} \cdot 4 \mathrm{H}_{2} \mathrm{O}$ & 0.18 & 0.09 \\
$\mathrm{FeCl}_{3} \cdot 6 \mathrm{H}_{2} \mathrm{O}$ & 0.76 & 0.38 \\
$\mathrm{Titriplex} 3(\mathrm{EDTA})$ & 1.5 & 0.75 \\
\hline
\end{tabular}


1,500 mL Steinberg medium diluted 1:1 with deionized water (see Figure 4). To avoid floating of the head whorls, the artificial sediment was weighed with $2 \mathrm{~g}$ of quartz sand. The artificial sediment was composed of OECD sediment [35], saturated with the Steinberg medium [36] according to [37]. The tests were performed in climate chambers with a constant temperature of $22 \pm 2^{\circ} \mathrm{C}$ and a light/dark rhythm of $16 / 8$. The light intensity was about 6,000 Lux. The atrazine application was performed with $0.009 \%$ ethanol as a solvent. The 2,4-D application was performed without a solvent. The nominal concentrations of atrazine were 10, 40,160, and $640 \mu \mathrm{g} / \mathrm{L}$. The nominal concentrations of 2,4-D were 7, 31.25, 125, 500, and 2,000 $\mu \mathrm{g} / \mathrm{L}$. Three $2,000-\mathrm{mL}$ beakers each with three test organisms were used for one treatment group, control group (C), or solvent control group (SC). Thus, each treatment group consists of three replicates, and in total, nine individual plants are respectively pseudoreplicates. The duration was 7 days for all six tests.

\section{Endpoints}

The growth rates of the following endpoints were determined:

1. fresh weight (g)

2. shoot length $(\mathrm{cm})$

3. root length by the longest root $(\mathrm{cm})$

The average specific growth rate for fresh weight and shoot length is calculated according to the following formula:

$$
\mu=\frac{1}{9} \sum_{i=1}^{9} \mu_{i} \quad \text { where } \quad \mu_{i}=\left(\ln \left(N_{e}\right)-\ln \left(N_{s}\right)\right) / 7
$$

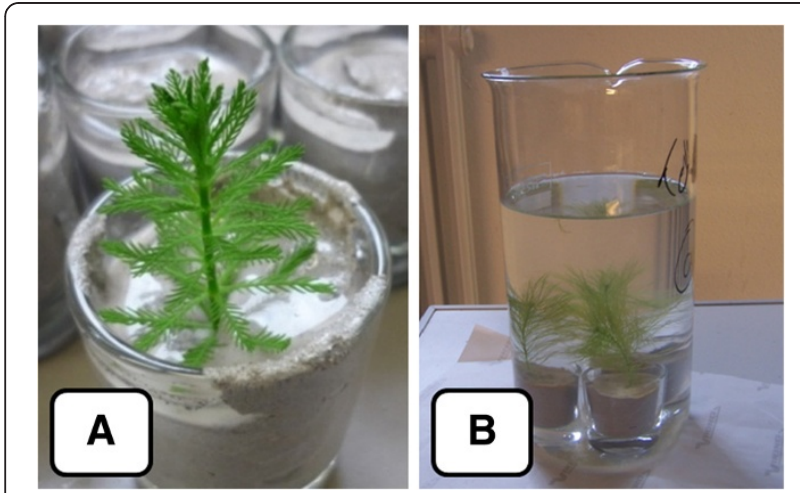

Figure 4 Head whorl and three pseudoreplicates. (A) Head whorl in $50 \mathrm{~g}$ of artificial sediment in a 40-mL beaker (test organism with no submerged adaptation). (B) Three pseudoreplicates in one 2,000-mL beaker with 1,500-mL medium (test organisms with 28-day submerged adaptation time).
Because for root length $N_{\mathrm{s}}$ would be 0 , only a linear growth rate calculation is possible according to the formula:

$$
\mu=\frac{1}{9} \sum_{i=1}^{9} \mu_{i} \quad \text { where } \quad \mu_{i}=N_{e} / 7
$$

$\mu$ is the average specific growth rate; $N_{\mathrm{s}}$, the fresh weight or shoot length at the start of the test; and $N_{\mathrm{e}}$, the fresh weight, shoot length, or root length at the end of the test.

\section{Measurements of the quantum yield}

At the start and the end of the atrazine tests, measurements of the quantum yield of the PSII were performed using a Mini-PAM (Walz GmbH, Effeltrich, Germany) with a leaf clip extension. The principles of this method are described in [38-40]. The quantum yield of the PSII correlates with photosynthetic carbon assimilation [38] and indicates inhibition of photosynthetic activity by a stressor $[41,42]$. For these measurements, the test organisms had to be taken off the medium.

The average specific quantum yield of the PSII is calculated according to the following formula:

$$
\begin{aligned}
\bar{\Phi}_{\mathrm{PSII}} & =\frac{1}{9} \sum_{i=1}^{9} \Phi_{\mathrm{PSII} i} \text { where } \Phi_{\mathrm{PSII} i} \\
& =\left(F_{m}^{\prime}-F_{t}\right) / F_{m}^{\prime} .
\end{aligned}
$$

$\bar{\Phi}_{\text {PSII }}$ is the average specific quantum yield of the PSII; $F_{\mathrm{m}}{ }^{\prime}$, the maximum fluorescence, and $F_{\mathrm{t}}$, the steady state fluorescence.

\section{Statistical analysis}

The percentage inhibition of growth rate regarding fresh weight, shoot length, and root length is calculated for each treatment group with the following formula:

$$
\begin{array}{ll}
\text { atrazine tests : } & \% I_{\mathrm{GR}}=\left(\mu_{\mathrm{SC}}-\mu_{\mathrm{TG}}\right) / \mu_{\mathrm{SC}} \times 100 \\
2,4-D \text { tests : } & \% I_{\mathrm{GR}}=\left(\mu_{C}-\mu_{\mathrm{TG}}\right) / \mu_{C} \times 100,
\end{array}
$$

$\% I_{\mathrm{GR}}$ is the percentage inhibition of growth rate; $\mu_{\mathrm{SC}}$, the average specific growth rate of the solvent control group; $\mu_{\mathrm{C}}$, the average specific growth rate of the control group; and $\mu_{\mathrm{TG}}$, the average specific growth rate of the treatment group.

Percentage inhibition of the quantum yield of PSII is calculated for each treatment group with the following formula:

$$
\% I_{\mathrm{QY}}=\left(\bar{\Phi}_{\mathrm{PSII} \mathrm{SC}}-\bar{\Phi}_{\mathrm{PSII} \mathrm{TG}}\right) / \bar{\Phi}_{\mathrm{PSII} \mathrm{SC}} \times 100,
$$

where $\% I_{\mathrm{QY}}$ is the percentage inhibition of the quantum yield of PSII; $\bar{\Phi}_{\text {PSII SC }}$, the average specific quantum yield 
of PSII of the solvent control group; and $\bar{\Phi}_{\mathrm{PSII}}$ TG , the average specific quantum yield of PSII of the treatment group.

The lowest observed effect concentrations (LOEC) and the no observed effect concentrations (NOEC) were determined using Dunnet's multiple comparison test (oneway ANOVA). The EC50 estimations were conducted by non-linear regression analysis of the concentrationresponse curve. The data analysis in this study was performed with the software Graphpad Prism 5.0.

\section{Chemical analysis}

Analysis of atrazine and 2,4-D was based on [43] and [44]. Samples were taken $1 \mathrm{~h}$ after 2,4-D and atrazine application of the test and were refrigerated at $-20^{\circ} \mathrm{C}$. In the laboratory, $0.5 \mathrm{~mL}$ of the water samples was mixed with $0.5 \mathrm{~mL}$ methanol. The stock solutions and the highest test concentration of the test substances atrazine and 2,4-D were analyzed by high performance liquid chromatography, Agilent 1200, Santa Clara, CA, USA) with a Merck Supersphere C18E column (Darmstadt, Germany). As the mobile phase for the 2,4-D measurements, water, acetonitrile, and an acetonitrile buffer $(\mathrm{pH} 2.01)$ were used in a gradient of 40 to $70 \%$ acetonitrile in $15 \mathrm{~min}$. The flow rate was $0.35 \mathrm{~mL} / \mathrm{min}$. The oven temperature was set at $40^{\circ} \mathrm{C}$. The detection of 2,4-D was carried out at a wavelength of $227 \mathrm{~nm}$. The mobile phase for the substance atrazine consisted of $68.5 \%$ water and $31.5 \%$ acetonitrile. The flow rate was $1 \mathrm{~mL} / \mathrm{min}$. The oven temperature was set at $40^{\circ} \mathrm{C}$. The detection of atrazine was carried out at a wavelength of $225 \mathrm{~nm}$. All concentration calculations were based on external standard samples. The measured samples were in the range of the calibration curves.

\section{Additional files}

Additional file 1: Lotus effect. Submergence of $M$. aquaticum head whorl without adaptation to the submerged state.

Additional file 2: No lotus effect. Submergence of $M$. aquaticum head whorl with adaptation to the submerged state.

\section{Competing interests}

The authors declare that they have no competing interests.

\section{Authors' contributions}

KPE conceived the study and participated in its design and implementation, final data analysis and final manuscript preparation. CF participated in the design of the study, data collection, and chemical analysis. LD participated in the design and implementation of the study, primary data analysis and draft manuscript preparation. All authors read and approved the final manuscript.

\section{Acknowledgments}

The authors thank the working group of PD Dr. Rolf-Alexander Düring (Giessen University, Germany) for the analytical supply. The present study was prepared at the Mesocosm $\mathrm{GmbH}$ which is a partner of the Biodiversity and Climate Research Centre (BiK-F), Frankfurt a.M., and financially supported by the research funding program 'LOEWE - Landes-Offensive zur Entwicklung Wissenschaftlich-ökonomischer Exzellenz' of Hesse's Ministry of Higher Education, Research, and the Arts.

\section{Author details}

${ }^{1}$ Institute for Water Protection MESOCOSM GmbH, Research Centre Neu-Ulrichstein, Homberg (Ohm) 35315, Germany. ${ }^{2}$ Institute for Landscape Ecology and Resources Management, Justus-Liebig-University Gießen,

Giessen 35390, Germany.

Received: 19 November 2012 Accepted: 18 February 2013

Published: 5 March 2013

\section{References}

1. Carpenter SR: Effects of submersed macrophytes on ecosystem processes. Aquat Bot 1986, 26:341-370.

2. Joniak T, Kuczynska-Kippen N, Nagengast: The role of aquatic macrophytes in microhabitual transformation of physical-chemical features of small water bodies. Hydrobiologia 2007, 584:101-109.

3. Gregg WW, Rose FL: Influences of aquatic macrophytes on invertebrate community structure, guild structure and microdistribution in streams. Hydrobiologia 1985, 128:45-56.

4. Hargeby A, Andersson G, Blindow I, Johansson S: Trophic web structure in a shallow eutrophic lake during a dominance shift from phytoplankton to submerged macrophytes. Hydrobiologia 1994, 279-280:83-90.

5. Lodge DM: Herbivory on freshwater macrophytes. Aquat Bot 1991, 41:195-224.

6. Lürling M, Van Geest G, Scheffer M: Importance of nutrient competition and allelopathic effects in suppression of the green alga Scenedesmus obliquus by the macrophytes Chara, Elodea and Myriophyllum. Hydrobiologia 2006, 556:209-220.

7. European Commission: Guidance Document on Aquatic Ecotoxicology in the context of the Directive 91/414/EEC. http://ec.europa.eu/food/plant/ protection/evaluation/guidance/wrkdoc10 en.pdf.

8. Brock TCM, Lahr J, van den Brink PJ: Ecological Risks of Pesticides in Freshwater Ecosystems. Part 1: herbicides. Wageningen: Alterra Green World Research; 2000. Alterra-Rapport 088

9. Vervliet-Scheebaum M, Knauer K, Maund SJ, Grade R, Wagner E: Evaluating the necessity of additional plant testing by comparing the sensitivities of different species. Hydrobiologia 2006, 570:231-236.

10. Maletzki D, Hünken A, Hübner I, Kussatz C: Myriophyllum spicatum als ökotoxikologischer Testorganismus: Methodenentwicklung eines sedimentfreien Testsystems und erste Ergebnisse mit 3,5-Dichlorphenol. Umweltwiss Schadst Forsch 2010, 22:702-710

11. SETAC: Aquatic macrophyte risk assessment for pesticides. In SETAC Europe Workshop AMRAP, Wageningen, Netherlands. Edited by Maltby L, Arnold D, Arts GHP, Davies J, Heimbach F, Pickl C, Poulsen V. Boca Raton: SETAC; 2010.

12. Arts GHP, Davies J, Dobbs M, Ebke $P$, Hanson M, Hommen U, Knauer K Loutseti S, Maltby L, Mohr S, Poovey A, Poulsen V: AMEG: the new SETAC advisory group on aquatic macrophyte ecotoxicology. Environ Sci Pollut Res 2010, 17:820-823.

13. Dören L: Entwicklung von Biotests mit Makrophyten: Makrophyten in der Ökotoxikologie - Hintergründe und neue Ansätze. Saarbrücken: Suedwestdeutscher Verlag für Hochschulschriften; 2010.

14. Knauer K, Mohr S, Feiler U: Comparing growth development of Myriophyllum spp. in laboratory and field experiments for ecotoxicological experiments. Environ Sci Pollut Res 2008, 15:322-331.

15. Wells LW, Pigliucci M: Adaptive phenotypic plasticity: the case of heterophylly in aquatic plants. Perspect Plant Ecol Evol Systemat 2000, 3(1):1-18.

16. Neinhuis C, Barthlott W: Characterization and distribution of waterrepellent, self-cleaning plant surfaces. Ann Bot 1997, 79:667-677.

17. Koch K, Bhushan B, Barthlott W: Multifunctional surface structures of plants: an inspiration for biomimetics. Progr Mater Sci 2009, 54:137-178.

18. Teodorović I, Knežević V, Tunić T, Čučak M, Lečić JN, Leovac A, Tumbas II: Myriophyllum aquaticum versus Lemna minor: sensitivity and recovery potential after exposure to atrazine. Environ Toxicol Chem 2012, 31(2):417-426

19. Fairchild JF, Ruessler DS, Carlson AR: Comparative sensitivity of five speciess of macrophytes and six speciess of algae to atrazine, metribuzin, alachlor and metolachlor. Environ Toxicol Chem 1998, 17(9): 1830-1834. 
20. Turgut C, Fomin A: Establishment of standardized growth conditions of Myriophyllum aquaticum (Vell.) verdcourt for testing sediment toxicity. J Appl Bot 2001, 75(1-2):80-84.

21. Turgut C, Fomin A: Sensitivity of the rooted macrophyte Myriophyllum aquaticum (Vell.) verdcourt to seventeen pesticides determined on the basis of EC50. Arch Environ Contam Toxicol 1997, 32:353-357.

22. Belgers JDM, van Lieverloo RJ, van der Pas LJT, van den Brink PJ: Effects of the herbicide 2,4-D on the growth of nine aquatic macrophytes. Aquat Bot 2007, 86:260-268.

23. European Commission: Review report for the active substance 2,4-D. 2,4-D 7599/VI/97-final. European Commission, Health \& Consumer Protection Directorate-General. http://ec.europa.eu/food/plant/protection/evaluation/ existactive/list1_2-4-d_en.pdf.

24. Osborne DJ: Ethylene and plants of aquatic and semi-aquatic environments: a review. Plant Growth Regul 1984, 2:167-185.

25. Voesenek LACJ, Rijnders JHGM, Peeters AJM, van de Steeg HM, de Kroon H: Plant hormones regulate fast shoot elongation underwater: from genes to communities. Ecology 2004, 85:16-27.

26. Jackson MB: Ethylene-promoted elongation: an adaptation to submergence stress. Ann Bot 2008, 101(2):229-248.

27. Groeneveld HW, Voesenek LACJ: Submergence-induced petiole elongation in Rumex palustris is controlled by developmental stage and storage compounds. Plant Soil 2003, 253(1):115-123.

28. Voesenek LACJ, Vriezen WH, Smekens MJE, Huitink FHM, Bogemann CM, Blom CWPM: Ethylene sensitivity and response sensor expression in petioles of Rumex speciess at low $\mathrm{O}_{2}$ and high $\mathrm{CO}_{2}$ concentrations. Plant Physiol 1997, 114:1501-1509.

29. Ebert E, van Assche CJ: Influence of atrazine (2-chloro-4-ethylamino-6isopropylamino-s-triazine) on auxin metabolism of plants. Cell Mol Life Sci 1969, 25(7):758-759.

30. Copping LG, Davis DE, Pillai CGP: Growth regulator-like activity of atrazine and ametryne. Weed Sci 1972, 20(3):274-277.

31. Raghavan C, Ong EK, Dalling MJ, Stevenson TW: Regulation of genes associated with auxin, ethylene and ABA pathways by 2,4-dichlorophenoxyacetic acid in Arabidopsis. Funct Integr Genomics 2006, 6:60-70.

32. Grossmann K: Mode of action of auxin herbicides: a new ending to a long, drawn out story. Trends Plant Sci 2000, 5(12):506-508.

33. Arts GHP, Belgers JDM, Hoekzema CH, Thissen JTNM: Sensitivity of submersed freshwater macrophytes and endpoints in laboratory toxicity tests. Environ Pollut 2008, 153:199-206.

34. van de Weyer K, Schmidt C: Bestimmungsschlüssel für die aquatischen Makrophyten (Gefäßpflanzen, Armleuchteralgen und Moose) in Deutschland. http://www.mugv.brandenburg.de/cms/detail.php/bb2.c.416666.de.

35. OECD: Earthworm, acute toxicity testing. OECD guidelines for the testing of chemicals 207. http://www.oecd-ilibrary.org/environment/test-no-207earthworm-acute-toxicity-tests_9789264070042-en.

36. OECD: Lemna sp. growth inhibition test. OECD Guidelines for the testing of chemicals 221. http://www.oecd-ilibrary.org/environment/test-no-221-lemnasp-growth-inhabition-test_9789264016194-en.

37. Feiler U, Kirchesch I, Heininger P: A new plant-based bioassay for aquatic sediments. J Soils Sediments 2004, 4:261-266.

38. Genty B, Briantais J-M, Baker NR: The relationship between quantum yield of photosynthetic electron transport and quenching of chlorophyll fluorescence. Biochim Biophys Acta 1989, 990:87-92.

39. Maxwell K, Johnson GN: Chlorophyll flourescence - a practical guide. J Exp Bot 2000, 51(345):659-668.

40. Roháček K, Barták M: Technique of the modulated chlorophyll fluorescence: basic concepts, useful parameters, and some applications. Photosynthetica 1999, 37(3):339-363.

41. Snell JFH, Vos JH, Gylstra R, Brock TCM: Inhibition of photosystem II (PSII) electron transport as a convenient endpoint to assess stress of the herbicide linuron on freshwater plants. Aquat Ecol 1998, 32:113-123.

42. Marwood CA, Solomon KR, Greenberg BM: Chlorophyll fluorescence as a bioindicator of effects on growth in aquatic macrophytes from mixtures of polycyclic aromatic hydrocarbons. Environ Toxicol Chem 2001, 20(4):890-898.
43. Shaner DL, Henry WB, Krutz LJ, Hanson B: Rapid assay for detecting enhanced atrazine degradation in soil. Weed Sci 2007, 55(5):528-535.

44. Arts GHP, Buijse-Bogdan LL, Belgers JDM, van Rhenen-Kersten $\mathrm{CH}$, van Wijngaarden RPA, Roessink I, Maund SJ, van den Brink PJ, Brock TCM: Ecological impact in ditch mesocosms of simulated spray drift from a crop protection program for potatoes. Integr Environ Assess Manag 2006, 2(2):105-125.

doi:10.1186/2190-4715-25-6

Cite this article as: Ebke et al:: Impact of heterophylly on the sensitivity of Myriophyllum aquaticum biotests. Environmental Sciences Europe 2013 25:6.

\section{Submit your manuscript to a SpringerOpen ${ }^{\odot}$ journal and benefit from:}

- Convenient online submission

- Rigorous peer review

- Immediate publication on acceptance

- Open access: articles freely available online

- High visibility within the field

- Retaining the copyright to your article

Submit your next manuscript at $>$ springeropen.com 